\title{
ANALISIS HUKUM PEMBERIAN HIBAH DARI PEMERINTAH KABUPATEN KUANTAN SINGINGI UNTUK PEMBANGUNAN PERGURUAN TINGGI SWASTA
}

\author{
Oleh: Rismahayani \\ Dosen Prodi Ilmu Hukum, Fak. Ilmu Sosial Universitas Islam Kuantan Singingi \\ Email: hayani.risma@yahoo.co.id
}

\begin{abstract}
Abstrak
Masalah pelaksanaan hibah di daerah pada umumnya karena penyalahgunaan, dikorup, tidak tepat waktu, dan sasaran. Pelaksanaan bantuan hibah dari Pemerintah Kabupaten Kuantan Singingi untuk pembangunan perguruan tinggi swasta kurang berjalan baik, bahkan terjadi penghentian, padahal sudah dianggarkan dua kali berturut-turut. Permasalahan dalam penelitian ini: Pertama, bagaimana tujuan, persyaratan dan pertanggungjawaban hibah dari Pemerintah Daerah? Kedua, bagaimana analisis hukum pemberian hibah dari Pemerintah Kabupaten Kuantan Singingi untuk pembangunan perguruan tinggi swasta? Penelitian ini merupakan penelitian hukum normatif atau penelitian hukum doktrinal dengan memfokuskan dari aspek inventarisasi hukum positif. Hasil penelitian ini diketahui bahwa tujuan, persyaratan dan pertanggungjawaban hibah dari pemerintah daerah sekarang dapat berpedoman pada Permendagri Nomor 32 Tahun 2011 yang telah diubah dengan Permendagri Nomor 39 Tahun 2012. Berlakunya Permendagri maka pemberian hibah sejak tahun anggaran 2012 menjadi semakin selektif dan ketat untuk mengantisipasi terjadinya penyimpangan mulai dari proses pengajuan proposal atau permohonan hibah, penganggaran oleh pemerintah daerah, penetapan dan penyaluran dana hibah, sampai dengan pertanggungjawaban serta monitoring dan evaluasi. Analisis hukum hibah dari Pemerintah Kabupaten Kuantan Singingi untuk pembangunan perguruan tinggi swasta yang menjadi persoalan karena telah dua kali dianggarkan setiap tahun berturut-turut dengan nomenklatur yang sama, namun pembangunan fisik tetap tidak terselesaikan. Bila dikaji dari hukum tentu sudah bertentangan dengan Permendagri Nomor 32 Tahun 2011 tentang Pedoman Pemberian Hibah dan Bantuan Sosial yang Bersumber Dari Anggaran Pendapatan dan Belanja Daerah pada Pasal 4 Ayat (4) huruf (b) di mana "tidak wajib, tidak mengikat dan tidak terus menerus setiap tahun anggaran, kecuali ditentukan lain oleh peraturan perundang-undangan.
\end{abstract}

\begin{abstract}
Grant implementation problems in the area in general because of the abuse, corrupted, not timely, and objective. Implementation grants from Singingi Kuantan District Government for the construction of private colleges not run well, even termination, but already budgeted two times in a row. The problem in this research: First, how the objectives, requirements and grants from local government accountability? Second, how the legal analysis of the grant from the Government of Kuantan Singingi for the construction of private universities? This research is a normative legal or doctrinal legal research by focusing on the positive aspects of the legal inventory. The results of this research note that the objectives, requirements
\end{abstract}


and responsibilities of the local government grants can now be based on the Regulation No. 32 of 2011, as amended by Regulation No. 39 of 2012. Applicability Permendagri then grants since budget year 2012 are becoming increasingly selective and rigorous in anticipation of deviation from the proposal submission process, or for grants, budgeting by local governments, the determination and distribution of grant funds, through accountability and monitoring and evaluation. Grant legal analysis of Singingi Kuantan District Government for the construction of private colleges that be a problem because it has twice the budgeted each year in a row with the same nomenclature, but the physical development remain unresolved. When examined from the law would have been contradicting with Regulation No. 32 Year 2011 on Guidelines for Grants and Social Assistance Sourced From Budget Revenue and Expenditure in Article 4 Paragraph (4) (b) where the "not mandatory, non-binding and does not continue constantly each financial year, unless otherwise stipulated by legislation.

\section{Kata kunci: Hibah, Kabupaten Kuantan Singingi, Permendagri}

\section{Pendahuluan}

Belanja bantuan hibah merupakan salah satu rekening belanja dalam Anggaran Pendapatan dan Belanja Daerah (APBD) yang menarik perhatian publik dan seringkali menjadi tajuk utama pada media massa. Hal tersebut dikarenakan banyak pihak yang membutuhkan bantuan hibah tersebut dan banyak kepentingan yang dapat diakomodir, baik untuk kepentingan kesejahteraan masyarakat maupun kepentingan politik tertentu.

Pemberian hibah oleh pemerintah daerah dilakukan setelah memprioritaskan pemenuhan belanja urusan wajib dengan memperhatikan asas keadilan, kepatutan, rasionalitas dan manfaat untuk masyarakat. Dalam arti kata, pemberian hibah dan bantuan sosial dapat diberikan jika seluruh belanja urusan wajib sudah terpenuhi atau tidak ada lagi belanja satuan kerja (urusan wajib) yang tidak teranggarkan dalam anggaran belanja, yaitu pendidikan, kesehatan, pekerjaan umum, perumahan rakyat, penataan ruang, perencanaan pembangunan, perhubungan, lingkungan hidup, pertanahan, kependudukan dan catatan sipil, pemberdayaan perempuan, keluarga berencana, sosial, tenaga kerja, koperasi dan usaha kecil dan menengah, penanaman modal, kebudayaan, pemuda dan olahraga, kesbangpol, kepegawaian, pemberdayaan masyarakat dan desa, statistik, arsip dan komunikasi dan informatika.

Hibah merupakan perbuatan hukum perdata. Hukum perdata sendiri berisi mengenai aturan-aturan hukum yang mengatur tingkah laku setiap orang terhadap orang lain yang berkaitan dengan hak dan kewajiban yang timbul dalam pergaulan masyarakat maupun keluarga. Kitab Undang-Undang Hukum Perdata (KUH Perdata) yang dikenal dengan istilah Bugerlijk Wetboek (BW) merupakan kodifikasi hukum perdata Belanda yang sebagian besar serupa dengan Code Civil Prancis (kodifikasi hukum perdata Prancis). ${ }^{1}$

Menurut KUH Perdata Pasal 1666 bahwa hibah suatu persetujuan dengan mana si penghibah diwaktu hidupnya dengan cumacuma dan dengan tidak dapat ditarik kembali,

${ }^{1}$ Abdulkadir Muhammad, Hukum Perdata Indonesia, (Bandung: Citra Aditya Bakti, 1990), hlm. 5. 
menyerahkan sesuatu benda guna keperluan si penerima hibah yang menerima penyerahan itu. Unsur penting yang terdapat di dalam perjanjian hibah ialah "murah hati" dan "tanpa pamrih. ${ }^{2}$ Penghibahan termasuk perjanjian sepihak, di mana hanya satu pihak saja yang mempunyai kewajiban atas perjanjian ini, yaitu si penghibah, sedangkan pihak yang menerima hibah sama sekali tidak mempunyai kewajiban. Penghibahan termasuk perjanjian "dengan cuma-cuma" (om niet) di mana perkataan "dengan cuma-cuma" itu ditujukan pada hanya adanya prestasi dari satu pihak saja, sedang pihak yang lainnya tidak usah memberikan kontra-prestasi sebagai imbalan. Perjanjian yang demikian juga dinamakan "sepihak" (unilateral) sebagai lawan dari perjanjian "bertimbal-balik" (bilateral). Semua orang boleh memberikan dan menerima hibah, kecuali yang oleh undang-undang dinyatakan tidak mampu untuk itu.

Menurut hukum Islam, hibah memiliki berbagai definisi yang berbeda-beda. Hal tersebut dikarenakan perbedaan pendapat ahli ilmu agama dan ahli hukum Islam, sedangkan kata hibah adalah bentuk masdar dari kata wahaba artinya memberi. ${ }^{3}$ Jika subyeknya Allah, berarti memberi karunia atau menganugrahi (Q.S. Ali Imran, 3:8, Maryam, 19:5, 49, 50, 53). Dalam pengertian istilah, hibah adalah pemilikan sesuatu benda melalui transaksi (Aqad) tanpa mengharap imbalan yang telah diketahui dengan jelas ketika pemberi masih hidup. ${ }^{4}$
Pengertian hibah dalam Ensiklopedi Hukum Islam adalah pemberian yang dilakukan secara sukarela dalam mendekatkan diri kepada Allah Swt tanpa mengharapkan balasan apapun. ${ }^{5}$ Dalam syara', hibah berarti akad yang pokok persoalan pemberian harta milik seseorang kepada orang lain diwaktu dia hidup, tanpa adanya imbalan. Apabila seseorang memberikan hartanya kepada orang lain untuk dimanfaatkan, tetapi tidak diberikan kepadanya hak pemilikan maka hal itu disebut i'aarah (pinjaman). ${ }^{6}$ Kompilasi Hukum Islam (KHI Pasal 171 huruf $\mathrm{g}$ ), hibah adalah pemberian suatu benda secara sukarela dan tanpa imbalan dari seseorang kepada orang lain yang masih hidup untuk dimiliki. ${ }^{7}$

Dalam pemberian hibah yang dilakukan oleh pemerintah khususnya pemerintah daerah benar-benar disesuaikan kepada kemampuan keuangan daerah sendiri dan harus tetap memprioritaskan pemenuhan belanja urusan wajib terlebih dahulu berdasarkan Pasal 21 Ayat (2) Peraturan Pemerintah (PP) Nomor 2 Tahun 2012 tentang Hibah Daerah menyatakan bahwa "Hibah dari Pemerintah Daerah dapat dianggarkan apabila Pemerintah Daerah telah memenuhi seluruh kebutuhan belanja urusan wajib guna memenuhi standar pelayanan minimum sesuai dengan ketentuan peraturan perundang-undangan, kecuali ditentukan lain dalam ketentuan peraturan perundangundangan".

Berdasarkan Peraturan Menteri Dalam Negeri Republik Indonesia Nomor 19 Tahun

${ }^{2}$ Tan Thong Kie, Studi Notariat, Serba-serbi Praktek Notaris, (Jakarta: Ichtiar Baru Van Hoeve, 2011), hlm. 579.

${ }^{3}$ A. W. Munawir, Kamus Al-Munawir, (Surabaya: Pustaka Progresif, 1997), hlm. 1584.

${ }^{4}$ Ahmad Rofiq, Hukum Islam di Indonesia, (Jakarta: PT Raja Grafindo Persada, 1998), hlm. 466.

${ }^{5}$ Abdul Aziz Dahlan, et.al., Ensiklopedi Hukum Islam, (Jakarta: PT Ichtiar van Hoeve, 1996), hlm. 540.

${ }^{6}$ Sayyid Sabiq, Fikih Sunnah, Jilid 14 (Terjemah), (Jakarta: Pena Pundi Aksara, 1997), hlm. 167.

${ }^{7}$ Tim Redaksi Fokusmedia, Kompilasi Hukum Islam, (Bandung: Fokusmedia, 2007), hlm. 56. 
2016 tentang Pedoman Pengelolaan Barang Milik Daerah dalam Pasal Bab VIII pemindahtanganan pada prinsip umum yang tertera pada Pasal 80 Ayat (2) menjelaskan bentuk pemindahtanganan barang milik daerah salah satunya adalah hibah. Aturan berkenaan dengan pemberian bantuan hibah oleh pemerintah daerah itu sendiri diperbolehkan berdasarkan PP Nomor 58 Tahun 2005 tentang Pengelolaan Keuangan Daerah dan Peraturan Menteri Dalam Negeri (Permendagri) Nomor 13 Tahun 2006 tentang Pedoman Pengelolaan Keuangan Daerah, yang telah diubah beberapa kali, terakhir dengan Pemendagri Nomor 21 Tahun 2011 tentang Perubahan Kedua atas Peraturan Menteri Dalam Negeri Nomor 13 Tahun 2006 tentang Pedoman Pengelolaan Keuangan Daerah. Namun, pengaturannya secara spesifik baru ditetapkan melalui Permendagri Nomor 32 Tahun 2011 tentang Pedoman Pemberian Hibah dan Bantuan Sosial yang bersumber dari Anggaran Pendapatan dan Belanja Daerah, yang telah disempurnakan kembali dengan Permendagri Nomor 39 Tahun 2012 tentang Perubahan atas Peraturan Menteri Dalam Negeri Nomor 32 Tahun 2011 tentang Pedoman Pemberian Hibah dan Bantuan Sosial yang bersumber dari Anggaran Pendapatan dan Belanja Daerah.

Peraturan terbaru berkenaan dengan pemberian hibah yang bersumber dari APBD dengan dikeluarkannya Permendagri Nomor 14 Tahun 2016 tentang Perubahan Kedua Atas Peraturan Menteri Dalam Negeri Republik Indonesia Nomor 32 Tahun 2011 tentang Pedoman Pemberian Hibah dan Bantuan Sosial yang Bersumber Dari Anggaran Pendapatan dan Belanja Daerah jelas pada Pasal 8 Ayat (1) dijelaskan dalam penganggaran untuk dana hibah kepala daerah menunjuk Satuan Kerja Perangkat Daerah
(SKPD) terkait untuk melakukan evaluasi usulan. Kemudian pada Ayat 2 juga dijelaskan kepala SKPD terkait sebagaimana dimaksud pada Ayat (2) menyampaikan hasil evaluasi berupa rekomendasi kepada kepala daerah melalui TAPD terakhir mekanisme yang harus dilalui dalam penganggaran untuk dana hibah di daerah TAPD memberikan pertimbangan atas rekomendasi sebagaimana dimaksud pada Ayat (3) sesuai dengan prioritas dan kemampuan keuangan daerah.

Dalam artikel ini hibah yang menjadi sorotan adalah hibah bersumber dari APBD Kabupaten Kuantan Singingi dalam kurun waktu 2015-2016 terkait hibah bangunan kampus perguruan tinggi swasta yang ada di Kabupaten Kuantan Singingi. Fenomena hibah di daerah pada umumnya terjadi penyalahgunaan, tidak tepat waktu dan sasaran, bahkan tidak sedikit yang tersandung kasus korupsi. Adapun permasalahan dalam artikel ini ada 2 (dua): Pertama, apakah tujuan, persyaratan dan pertanggungjawaban hibah dari pemerintah daerah? Kedua, bagaimana analisis hukum hibah dari Pemerintah Kabupaten Kuantan Sengingi untuk pembangunan perguruan tinggi swasta?

\section{Metode Penelitian}

Penelitian ini adalah penelitian hukum normatif atau penelitian hukum doktrinal dengan memfokuskan dari aspek inventarisasi hukum positif. Inventarisasi hukum positif merupakan kegiatan pendahuluan yang bersifat mendasar untuk melakukan penelitian hukum dari tipe-tipe yang lain. Melalui jenis penelitian ini dilakukan melalui proses identifikasi yang kritis-analitis dan selanjutnya melalui proses klasifikasi yang logis-sistematis. Jenis penelitian ini ini tidak berdiri sendiri, tetapi merupakan salah satu tahap dari rangkaian proses suatu 
penelitian yang menyeluruh. Sebagai penelitian hukum normatif maka sumber data yang dipergunakan adalah data sekunder, terdiri dari bahan hukum primer, sekunder dan tersier. Analisis data dalam penelitian ini dilakukan dengan suatu tahapan ilmiah dilakukan dengan cara kualitatif, yakni dibandingkan atau diterapkan ke dalam peraturan perundangundangan yang berlaku, pendapat para sarjana (doktrin), serta teori-teori hukum lainnya. Akhir dari pembahasan penelitian ini akan ditarik kesimpulan secara deduktif, yakni penarikan kesimpulan yang diawali oleh hal-hal yang bersifat umum kepada hal-hal yang bersifat khusus.

\section{Pembahasan}

Tujuan, Persyaratan dan Pertanggungjawaban Hibah Dari Pemerintah Daerah

Berdasarkan Kamus Besar Bahasa Indonesia, "hibah" berarti pemberian (dengan sukarela) dengan mengalihkan hak atas sesuatu kepada orang lain. Kata "hibah" memiliki 2 (dua) makna, yaitu hibah antarpersonal sebagaimana dimaksud dalam Kitab Undang-Undang Hukum Perdata (KUH Perdata) dan hibah terkait dengan keuangan daerah sesuai dengan objek tulisan hukum ini. Adapun ketentuan perundang-undangan hibah sebagai berikut:

1. Pasal 1666 KUH Perdata, menyatakan hibah/penghibahan (schenking) adalah suatu persetujuan/perjanjian (overeen-komst) dengan/dalam mana pihak yang menghibahkan (schenker), pada waktu ia masih hidup, secara cuma-cuma (omniet) dan tak dapat ditarik kembali, menyerahkan/ melepaskan sesuatu benda kepada/ demi keperluan penerima hibah (begiftigde) yang menerima penyerahan/penghibahan itu.
2. Penjelasan Pasal 27 Ayat (7) huruf f PP Nomor 58 Tahun 2005 tentang Pengelolaan Keuangan Daerah, menyatakan bahwa hibah digunakan untuk menganggarkan pemberian uang/barang atau jasa kepada pemerintah atau pemerintah daerah lainnya, perusahaan daerah, masyarakat, dan organisasi kemasyarakatan, yang secara spesifik telah ditetapkan peruntukannya, bersifat tidak wajib dan tidak mengikat, serta tidak secara terus menerus.

3. Pasal 42 Permendagri Nomor 13 Tahun 2006 tentang Pedoman Pengelolaan Keuangan Daerah, yang telah diubah beberapa kali terakhir dengan Pemendagri Nomor 21 Tahun 2011 tentang Perubahan Kedua atas Peraturan Menteri Dalam Negeri Nomor 13 Tahun 2006 tentang Pedoman Pengelolaan Keuangan Daerah, yang menyatakan bahwa belanja hibah digunakan untuk menganggarkan pemberian hibah dalam bentuk uang, barang dan/atau jasa kepada pemerintah atau pemerintah daerah lainnya, perusahaan daerah, masyarakat, dan organisasi kemasyarakatan yang secara spesifik telah ditetapkan peruntukannya.

4. Pasal 1 angka 14 Permendagri Nomor 32 Tahun 2011 tentang Pedoman Pemberian Hibah dan Bantuan Sosial yang bersumber dari Anggaran Pendapatan dan Belanja Daerah, yang telah diubah dengan Permendagri Nomor 39 Tahun 2012 tentang Perubahan atas Peraturan Menteri Dalam Negeri Nomor 32 Tahun 2011 tentang Pedoman Pemberian Hibah dan Bantuan Sosial yang bersumber 
dari Anggaran Pendapatan dan Belanja Daerah, pengertian hibah adalah pemberian uang/barang atau jasa dari pemerintah daerah kepada pemerintah atau pemerintah daerah lainnya, perusahaan daerah, masyarakat dan organisasi kemasyarakatan, yang secara spesifik telah ditetapkan peruntukannya, bersifat tidak wajib dan tidak mengikat, serta tidak secara terus menerus yang bertujuan untuk menunjang penyelenggaraan urusan pemerintah daerah.

5. PP Nomor 2 Tahun 2012 tentang Hibah Daerah dalam Ketentuan Umum Pasal 1 Ayat (10) menjelaskan hibah daerah adalah pemberian dengan pengalihan hak atas sesuatu dari pemerintah atau pihak lain kepada pemerintah daerah atau sebaliknya yang secara spesifik telah ditetapkan peruntukannya dan dilakukan melalui perjanjian.

6. Permendagri Nomor 14 Tahun 2016 tentang Perubahan Kedua Atas Peraturan Menteri Dalam Negeri Republik Indonesia Nomor 32 Tahun 2011 tentang Pedoman Pemberian Hibah dan Bantuan Sosial yang Bersumber Dari Anggaran Pendapatan dan Belanja Daerah dijelaskan dalam ketentuan umum Pasal 1 Ayat (14) di mana hibah adalah pemberian uang/barang atau jasa dari pemerintah daerah kepada pemerintah pusat atau pemerintah daerah lain, Badan Usaha Milik Negara/Badan Usaha Milik Daerah, Badan, lembaga dan organisasi kemasyarakatan yang berbadan hukum Indonesia, yang secara spesifik telah ditetapkan peruntukan-nya, bersifat tidak wajib dan tidak mengikat, serta tidak secara terus menerus yang bertujuan untuk menunjang penyelenggaraan urusan pemerintahan daerah.

7. Buletin Teknis Nomor 4 Standar Akuntansi Pemerintahan (SAP) tentang Penyajian dan Pengungkapan Belanja Pemerintah, menyatakan bahwa hibah adalah pengeluaran pemerintah dalam bentuk uang/barang atau jasa kepada pemerintah atau pemerintah lainnya, perusahaan daerah, masyarakat, dan organisasi kemasyarakatan, yang secara spesifik telah ditetapkan peruntukannya, bersifat tidak wajib dan tidak mengikat, serta tidak secara terus menerus. $^{8}$

8. Buletin Teknis Nomor 13 SAP tentang Akuntansi Hibah, yang menyatakan bahwa belanja hibah adalah belanja pemerintah dalam bentuk uang/barang atau jasa yang dapat diberikan kepada pemerintah negara lain, organisasi internasional, pemerintah pusat/ daerah, perusahaan negara/daerah, kelompok masyarakat, atau organisasi kemasyarakatan yang secara spesifik telah ditetapkan peruntukannya, bersifat tidak wajib dan tidak mengikat, serta tidak secara terus menerus kecuali ditentukan lain dalam peraturan perundang-undangan. ${ }^{9}$

Sesuai dengan pengertian hibah maka pemberian hibah dari pemerintah daerah

${ }^{8}$ Buletin Teknis Nomor 4 Standar Akuntansi Pemerintahan (SAP) tentang Penyajian dan Pengungkapan Belanja Pemerintah.

${ }^{9}$ Buletin Teknis Nomor 13 SAP tentang Akuntansi Hibah. 
bertujuan untuk menunjang penyelenggaran urusan pemerintah daerah. Pemberian hibah ditujukan untuk menunjang pencapaian sasaran program dan kegiatan pemerintah dengan tetap memperhatikan asas keadilan, kepatutan, rasionalitas, dan manfaat untuk masyarakat, serta sesuai dengan asas pengelolaan keuangan daerah. Asas-asas tersebut dapat dijelaskan sebagai berikut:

1. Asas keadilan, yaitu terdapat keseimbangan dalam distribusi kewenangan dan penyalurannya dan/ atau keseimbangan distribusi hak dan kewajiban berdasarkan pertimbangan objektif.

2. Asas kepatutan, yaitu tindakan atau suatu sikap yang dilakukan dengan wajar dan proporsional.

3. Asas rasionalitas, yaitu keputusan atas pemberian hibah harus tepat sasaran dan dapat dipertanggungjawabkan.

4. Asas manfaat untuk masyarakat, yaitu bahwa keuangan daerah harus diutamakan untuk pemenuhan kebutuhan masyarakat dan bermanfaat.

5. Asas pengelolaan keuangan daerah berarti bahwa keuangan daerah dikelola secara tertib, taat pada peraturan perundang-undangan, efektif, efisien, ekonomis, transparan, dan bertanggungjawab dengan memperhatikan asas keadilan, kepatutan, dan manfaat untuk masyarakat.

Bentuk hibah berdasarkan Pasal 3 Ayat (1) Permendagri Nomor 32 Tahun 2011 tentang Pedoman Pemberian Hibah dan Bantuan Sosial yang bersumber dari Anggaran Pendapatan dan Belanja Daerah, yang telah diubah dengan Permendagri Nomor 39 Tahun 2012 tentang Perubahan atas Peraturan
Menteri Dalam Negeri Nomor 32 Tahun 2011 tentang Pedoman Pemberian Hibah dan Bantuan Sosial yang bersumber dari Anggaran Pendapatan dan Belanja Daerah, pemberian hibah dapat berupa uang, barang, atau jasa.

Berlakunya Permendagri Nomor 32 Tahun 2011 tentang Pedoman Pemberian Hibah dan Bantuan Sosial yang bersumber dari Anggaran Pendapatan dan Belanja Daerah, yang kemudian disempurnakan kembali dengan Permendagri Nomor 39 Tahun 2012 tentang Perubahan atas Peraturan Menteri Dalam Negeri Nomor 32 Tahun 2011 tentang Pedoman Pemberian Hibah dan Bantuan Sosial yang bersumber dari Anggaran Pendapatan dan Belanja Daerah maka pemberian hibah sejak tahun anggaran 2012 menjadi semakin selektif dan ketat. Kriteriakriteria sebagai pembatasan pemberian hibah disyaratkan oleh Permendagri dan dapat mengantisipasi terjadinya penyimpangan dalam mekanisme pemberian hibah mulai dari proses pengajuan proposal atau permohonan hibah, penganggaran oleh pemerintah daerah, penetapan dan penyaluran dana hibah, sampai dengan pertanggungjawaban serta monitoring dan evaluasi atas pemberian dana hibah tersebut.

Pasal 42 Permendagri tersebut menekankan bahwa tata cara penganggaran, pelaksanaan dan penatausahaan, pertanggungjawaban dan pelaporan serta monitoring dan evaluasi hibah dan bantuan sosial harus diatur lebih lanjut dengan peraturan kepala daerah. Pemerintah daerah baru dapat menganggarkan belanja hibah setelah peraturan kepala daerah dimaksud ditetapkan dan berlaku dengan menyesuaikan kepada ketentuan Permendagri tersebut. Berarti, selain kriteria minimal yang dipersyaratkan oleh Permendagri, pemerintah daerah dapat menambahkan kriteria/persyaratan lain terkait 
hibah yang dinilai penting dan sesuai dengan karakteristik daerahnya selama tidak bertentangan dengan Permendagri.

Berikut penjelasan kriteria/persyaratan terkait pemberian hibah:

a. Kriteria atau syarat minimal pemberian hibah

1) Peruntukannya secara spesifik telah ditetapkan.

Hibah berupa uang harus dicantumkan secara lengkap dan jelas ke dalam dokumen Rencana Kerja dan Anggaran PPKD (RKA-PPKD) mulai dari jenis belanja hibah, obyek, dan rincian obyek belanja. Artinya, dalam menyusun RKA-PPKD tersebut sudah harus dipastikan dan ditetapkan nama penerima, jumlah/besaran nilai, dan peruntukan hibah tersebut. Anggaran belanja hibah, baik sebagian maupun keseluruhan, tidak dapat lagi dicantumkan secara gelondongan atau hanya sampai jenis belanja hibah saja. Peruntukan penggunaan hibah juga secara spesifik dicantumkan dalam peraturan kepala daerah, keputusan kepala daerah, dan Naskah Perjanjian Hibah Daerah (NPHD).

2) Tidak wajib, tidak mengikat dan tidak terus menerus setiap tahun anggaran, kecuali ditentukan lain oleh peraturan perundang-undangan.

Kriteria ini berarti pemerintah daerah tidak memiliki kewajiban untuk mengabulkan semua proposal/ permohonan bantuan hibah yang diajukan oleh calon penerima hibah, dana hibah diberikan sebagai bantuan kegiatan, bukan digunakan untuk dana operasional yang selalu diberikan setiap tahun anggaran, dengan pengecualian yang juga ditentukan dalam peraturan perundang-undangan, misalnya hibah untuk organisasi semi pemerintah seperti Tim Penggerak Pemberdayaan Kesejahteraan Keluarga (TP-PKK), Palang Merah Indonesia, Komite Olahraga Nasional Indonesia (KONI), Pramuka, maupun organisasi semi pemerintah lainnya.

3) Memenuhi persyaratan penerima hibah.

Penerima hibah dapat dijelaskan sebagai berikut:

(a) Pemerintah, yaitu satuan kerja dari kementerian kementerian/lembaga pemerintah non kementerian yang wilayah kerjanya berada dalam daerah yang bersangkutan, atau sering disebut sebagai hibah kepada instansi vertikal.

(b) Pemerintah daerah lainnya, yaitu hibah kepada daerah otonom baru hasil pemekaran daerah sebagaimana diamanatkan peraturan perundang-undangan.

(c) Perusahaan daerah, yaitu Badan Usaha Milik Daerah (BUMD) dalam rangka penerusan hibah yang diterima pemerintah daerah dari Pemerintah Pusat sesuai dengan ketentuan peraturan perundangundangan.

(d) Masyarakat, yaitu kelompok orang yang memiliki kegiatan tertentu dalam bidang perekonomian, pendidikan, kesehatan, keagamaan, kesenian, adat istiadat, dan keolahragaan non-profesional. Hibah kepada masyarakat ini diberikan dengan persyaratan minimal memiliki kepengurusan yang jelas dan berkedudukan dalam wilayah administrasi pemerintah daerah yang bersangkutan. 
(e) Organisasi kemasyarakatan yang dibentuk berdasarkan peraturan perundang-undangan. Hibah kepada organisasi kemasyarakatan ini diberikan dengan persyaratan minimal telah terdaftar pada pemerintah daerah setempat sekurang-kurangnya 3 tahun (kecuali ditentukan lain oleh peraturan perundang-undangan), berkedudukan dalam wilayah administrasi pemerintah daerah yang bersangkutan, dan memiliki sekretariat tetap.

Selain pengangaran hibah di APBD terdapat tanggung jawab kepala daerah untuk menunjuk SKPD terkait untuk melakukan evaluasi atas usulan/proposal/permohonan hibah tersebut, kepala SKPD lalu menyampaikan rekomendasi sebagai hasil evaluasi kepada kepala daerah melalui Tim Anggaran Pemerintah Daerah (TAPD). TAPD lalu memberikan pertimbangan atas rekomendasi tersebut sesuai dengan prioritas dan kemampuan keuangan daerah. TAPD dibentuk dengan keputusan kepala daerah dan dipimpin oleh sekretaris daerah yang mempunyai tugas menyiapkan serta melaksanakan kebijakan kepala daerah dalam rangka penyusunan APBD yang anggotanya terdiri dari pejabat perencana daerah, PPKD dan pejabat lainnya sesuai dengan kebutuhan.

Rekomendasi kepala SKPD dan pertimbangan TAPD dijadikan dasar pencantuman alokasi anggaran hibah dalam rancangan Kebijakan Umum Anggaran dan Prioritas dan Plafon Anggaran Sementara (KUA-PPAS). Rancangan KUA-PPAS itu selanjutnya akan dibahas dan disepakati oleh TAPD dengan Panitia Anggaran DPRD dan menjadi pedoman bagi PPKD untuk menetapkan RKA-PPKD.
Hibah berupa uang dicantumkan dalam RKAPPKD mulai dari jenis belanja hibah, obyek, dan rincian obyek belanja. RKA-PPKD menjadi dasar penganggaran hibah dalam APBD sesuai peraturan perundang-undangan. APBD selanjutnya ditetapkan melalui peraturan daerah (perda) dan penjabaran APBD ditetapkan melalui peraturan kepala daerah (perkada). Daftar nama penerima, alamat penerima, dan besaran hibah juga dicantumkan dalam Lampiran III Perkada tentang Penjabaran APBD.

Pelaksanaan anggaran hibah berupa uang berdasarkan atas apa yang ditetapkan dalam Dokumen Pelaksanaan Anggaran PPKD (DPA-PPKD), yaitu dokumen pelaksanaan anggaran berdasarkan Perda APBD dan Perkada Penjabaran APBD, kepala daerah lalu menetapkan daftar penerima hibah beserta besaran uang hibah melalui keputusan kepala daerah. Daftar penerima hibah tersebut menjadi dasar penyaluran/penyerahan hibah. Pencairan/penyaluran hibah dilakukan dengan mekanisme pembayaran langsung dari rekening Kas Daerah ke rekening penerima hibah. Selanjutnya, penyaluran/penyerahan hibah dari pemerintah daerah kepada penerima hibah dilakukan setelah penandatanganan NPHD bersama antara penerima hibah dengan kepala daerah atau pejabat yang diberinya wewenang untuk menandatangani NPHD. Sementara NPHD paling sedikit harus memuat:

a. pemberi dan penerima hibah.

b. tujuan pemberian hibah.

c. besaran/rincian penggunaan hibah yang akan diterima.

d. hak dan kewajiban.

e. tata cara penyaluran/penyerahan hibah.

f. tata cara pelaporan hibah.

Pertanggungjawaban pemerintah daerah atas pemberian hibah, meliputi: 
a. Usulan dari calon penerima hibah kepada kepala daerah.

b. Keputusan kepala daerah tentang penetapan daftar penerima hibah.

c. NPHD.

d. Pakta integritas dari penerima hibah yang menyatakan bahwa hibah yang diterima akan digunakan sesuai dengan NPHD.

e. Bukti transfer uang dari rekening Kas Daerah ke rekening penerima hibah.

Selanjutnya, yang menjadi pertanggungjawaban oleh penerima hibah, yakni penerima hibah bertanggung jawab secara formal dan material atas penggunaan dana hibah yang diterimanya. Dengan menerima bantuan hibah berupa uang dari pemerintah daerah yang bersumber dari APBD maka penerima hibah juga harus menyadari kewajibannya selaku obyek pemeriksaan, khususnya pemeriksaan oleh Badan Pemeriksa Keuangan. Pertanggungjawaban penerima hibah disampaikan kepada kepala daerah paling lambat tanggal 10 Januari tahun anggaran berikutnya, meliputi:

(a) Laporan penggunaan hibah, disampaikan kepada kepala daerah melalui PPKD dengan tembusan SKPD terkait.

(b) Surat pernyataan tanggung jawab yang menyatakan bahwa hibah yang diterima telah digunakan sesuai NPHD. Penggunaan/peruntukan hibah yang diterima harus sesuai dengan tujuan atau rencana kegiatan yang diajukan dalam usulan/proposal/permohonan hibah.

(c) Bukti-bukti pengeluaran yang lengkap dan sah sesuai peraturan perundangundangan. Bukti-bukti pengeluaran harus sesuai dengan nilai yang tercantum dalam laporan pertanggungjawaban.
Dalam Surat Edaran Mendagri tertanggal 18 Agustus 2015 poin 9 disebutkan dalam konteks penyelenggaraan pemerintah daerah dengan berlakunya Undang-Undang Nomor 23 Tahun 2014, untuk terciptanya harmonisasi, stabilisasi, efektivitas, dan menjamin partisipasi masyarakat guna memperkuat dukungan terhadap penyelenggaraan pemerintah daerah maka disampaikan bahwa yang dimaksud dengan badan, lembaga, dan organisasi kemasyarakatan yang berbadan hukum Indonesia sebagai berikut:

a. Badan dan lembaga yang berbadan hukum Indonesia adalah:

1) Badan dan lembaga kemasyarakatan yang bersifat nirlaba, sukarela, dan sosial yang dibentuk berdasarkan peraturan perundangundangan.

2) Badan dan lembaga kemasyarakatan yang bersifat nirlaba, sukarela, dan sosial yang telah memiliki Surat Keterangan Terdaftar (SKT) yang diterbitkan oleh Menteri Dalam Negeri, Gubernur, atau Bupati/ Walikota.

b. Organisasi kemasyarakatan yang berbadan hukum Indonesia adalah organisasi kemasyarakatan yang berbadan hukum yayasan atau organisasi kemasyarakatan yang berbadan hukum perkumpulan yang telah mendapatkan pengesahan badan hukum perkumpulan yang telah mendapatkan pengesahan badan hukum dari Kementerian Hukum dan Hak Asasi Manusia sesuai ketentuan peraturan perundang-undangan.

Pada poin 10, disebutkan dalam rangka menjamin kepastian hukum dan keberlangsungan serta efektivitas penyelenggaraan 
pemerintah daerah, efisiensi, transparansi, dan akuntabilitas pelaksanaan anggaran hibah dan bantuan sosial yang tercantum dalam Perda tentang APBD, sebelum diberlakukannya Undang-Undang Nomor 23 Tahun 2014 maka berlaku ketentuan bahwa penyediaan anggaran belanja hibah dan bantuan sosial dilaksanakan sepanjang telah dilakukan evaluasi dan mendapatkan rekomendasi dari Kepala SKPD terkait, memperoleh pertimbangan dari TAPD, dan tercantum dalam KUA/PPAS tahun anggaran berkenaan sesuai maksud Permendagri Nomor 32 Tahun 2011 sebagaimana diubah dengan Permendagri Nomor 39 Tahun 2012.

Adapun alur dalam pengangaran hibah dalam APBD dapat dilihat pada skema di bawah ini:

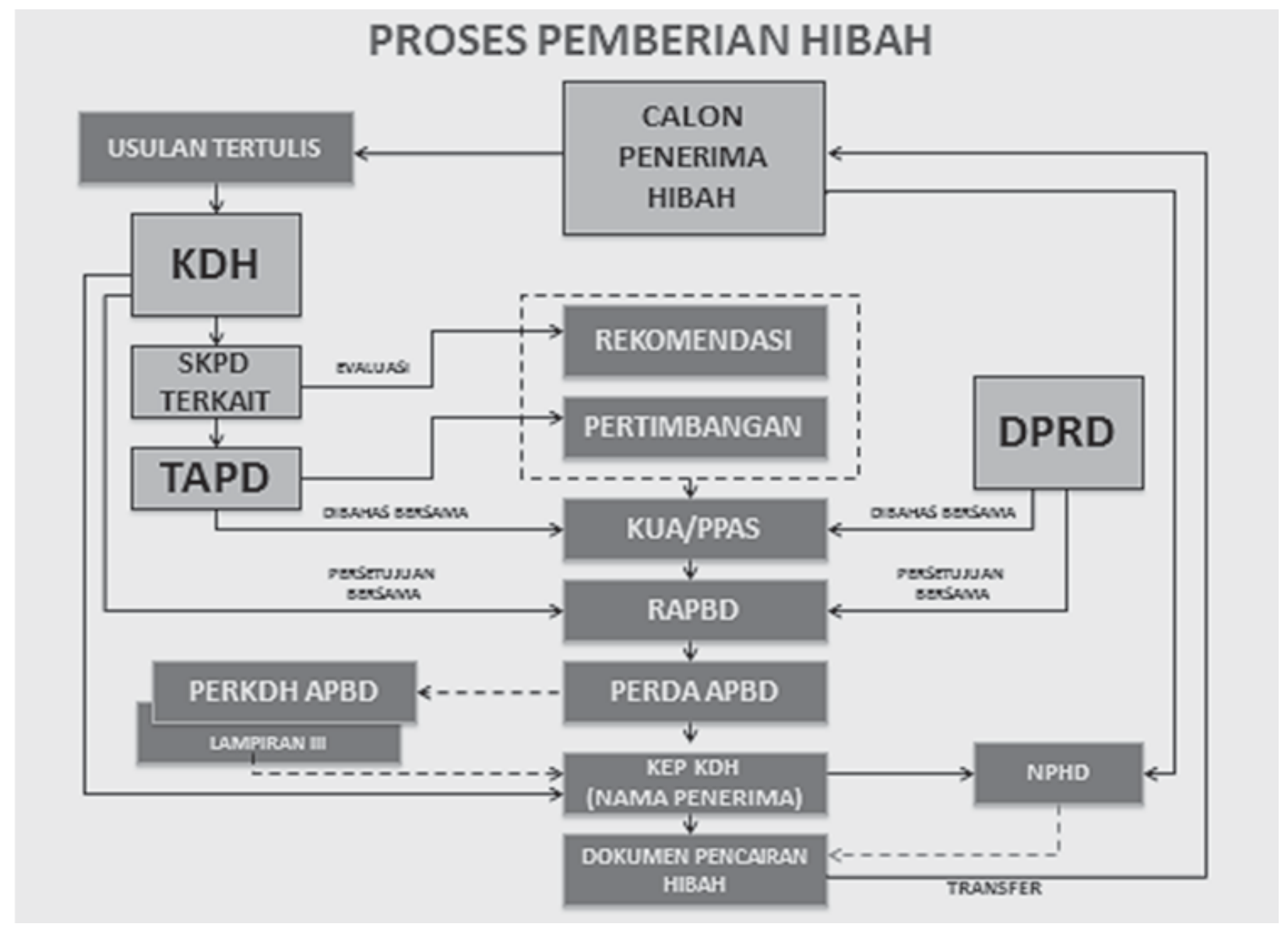




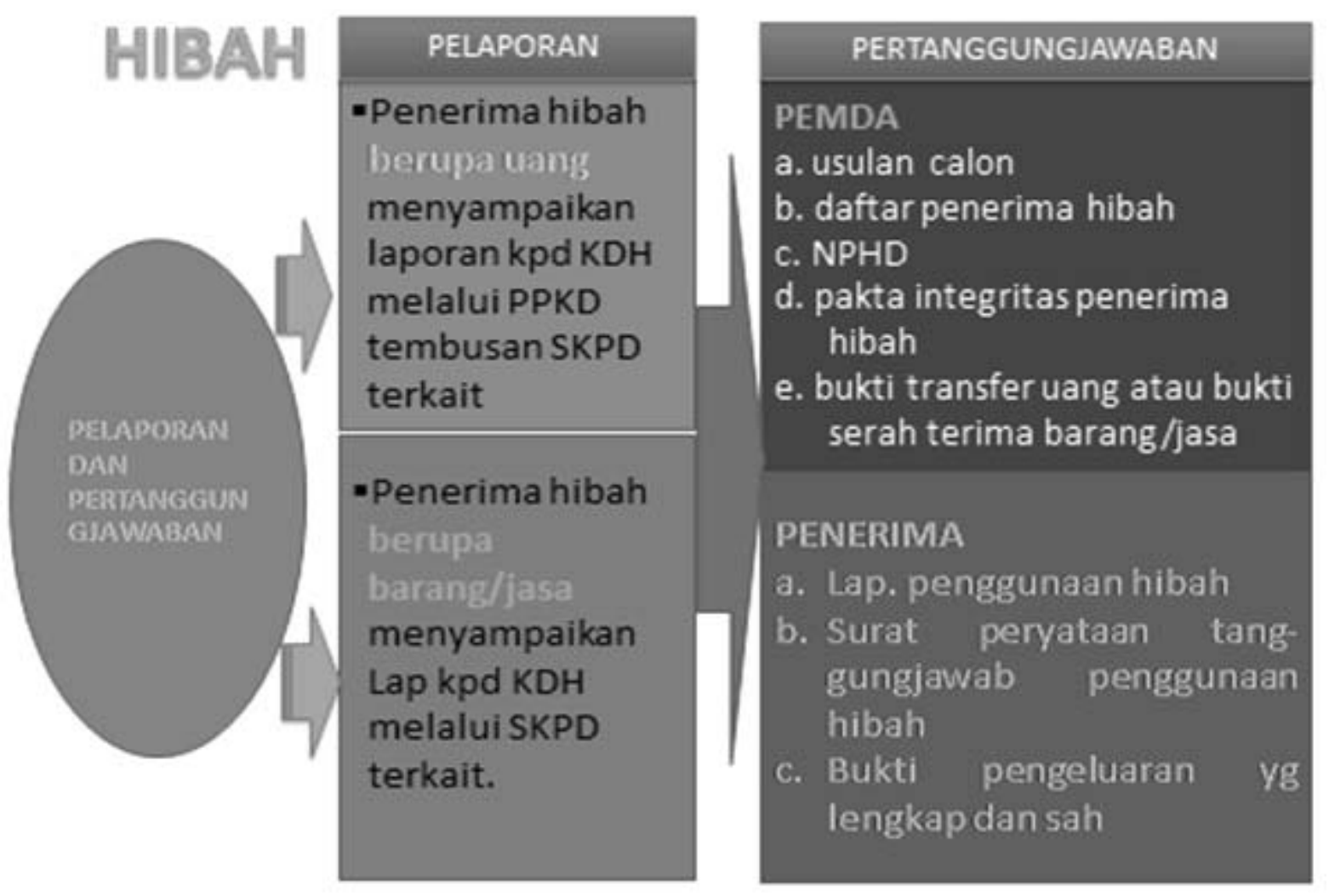

Cukup banyak dan ketatnya peraturan yang terkait dengan hibah yang dikeluarkan oleh pemerintah mulai dari PP Nomor 58 Tahun 2005 tentang Pengelolaan Keuangan Daerah dan Permendagri Nomor 13 Tahun 2006 tentang Pedoman Pengelolaan Keuangan Daerah, yang telah diubah beberapa kali terakhir dengan Pemendagri Nomor 21 Tahun 2011 tentang Perubahan Kedua atas Peraturan Menteri Dalam Negeri Nomor 13 Tahun 2006 tentang Pedoman Pengelolaan Keuangan Daerah. Namun, pengaturannya secara spesifik baru ditetapkan melalui Permendagri Nomor 32 Tahun 2011 tentang Pedoman Pemberian Hibah dan Bantuan Sosial yang bersumber dari Anggaran Pendapatan dan Belanja Daerah, yang telah disempurnakan kembali dengan Permendagri Nomor 39 Tahun 2012 tentang Perubahan atas Peraturan Menteri Dalam Negeri Nomor 32 Tahun 2011 tentang Pedoman Pemberian Hibah dan Bantuan Sosial yang bersumber dari Anggaran Pendapatan dan Belanja Daerah dan Peraturan Menteri Dalam Negeri Republik Indonesia Nomor 14 Tahun 2016 tentang Perubahan Kedua Atas Peraturan Menteri Dalam Negeri Republik Indonesia Nomor 32 tahun 2011 tentang Pedoman Pemberian Hibah dan Bantuan Sosial yang Bersumber Dari Anggaran Pendapatan dan Belanja Daerah telah memberikan tolok ukur yang jelas dan kriteria minimal dalam penganggaran dan pemberian hibah.

Ketentuan dalam Pasal 43 Permendagri Nomor 39 Tahun 2012 yang menyatakan bahwa dengan berlakunya Permendagri tersebut maka penganggaran, pelaksanaan dan penatausahaan, pelaporan dan pertanggungjawaban serta monitoring dan evaluasi pemberian hibah dan bantuan sosial mulai tahun anggaran 2013 harus berpedoman pada Permendagri tersebut, dan pasal-pasal dalam Permendagri Nomor 32 Tahun 2011 yang tidak diubah, tidak lagi 
memberikan alasan kepada pemerintah daerah untuk menyalurkan hibah dengan tidak terencana. Penganggaran dan pemberian hibah juga harus tetap memperhatikan ketentuan Permendagri tentang Pedoman Penyusunan Anggaran Pendapatan dan Belanja Daerah yang terbit untuk tiap tahun anggaran.

\section{Analisis Hukum Pemberian Hibah Dari Pemerintah Kabupaten Kuantan Singingi Untuk Pembangunan Perguruan Tinggi Swasta}

Belanja hibah sebagai salah satu komponen dari keuangan daerah yang setiap tahunnya dituangkan dalam APBD Kabupaten Kuantan Singingi selayaknya dikelola secara tertib, taat peraturan perundang-undangan, efisien, ekonomi, efektif, transparan dan bertanggung jawab dengan memperhatikan asas keadilan, kepatutan, rasionalitas dan manfaat untuk masyarakat. Hal ini ditujukan agar, tercipta tertib administrasi, akuntabilitas, transparansi pengelolaan bantuan dana hibah serta ketepatan dalam pengunaan dana bantuan oleh penerima dana bantuan hibah.

Selama ini perencanaan dan pelaksanaan kegiatan bantuan hibah yang dianggarkan dan dilaksanakan di Kabupaten Kuantan Singingi khususnya hibah bangunan kampus pada perguruan tinggi swasta di Kabupaten Kuantan Singingi kurang berjalan dengan baik bahkan terjadi penghentian pembangunan fisik kampus yang sudah dianggarkan sebanyak dua kali berturut-turut. Hal ini menjadi persoalan bila mengacu pada Permendagri Nomor 14 Tahun 2016 pada Pasal 8 Ayat (2) dengan ketentuan kepala daerah menunjuk SKPD terkait untuk melakukan evaluasi usulan sebagaimana dimaksud pada Ayat (1). Pada tataran ini dari penganggaran hibah untuk fisik kampus belum terlaksana yang menjadi persoalan sebanyak dua kali dianggarkan setiap tahun berturut-turut dalam APBD dengan nomenklatur anggaran hibah yang sama pembangunan fisik tetap tidak terselesaikan. Bila dikaji dari hukum tentu sudah bertentangan dengan Permendagri Nomor 32 Tahun 2011 tentang Pedoman Pemberian Hibah dan Bantuan Sosial yang Bersumber Dari Anggaran Pendapatan dan Belanja Daerah pada Pasal 4 Ayat (4) huruf (b) di mana "tidak wajib, tidak mengikat dan tidak terus menerus setiap tahun anggaran, kecuali ditentukan lain oleh peraturan perundang-undangan".

Dari pasal di atas sudah terjadi pelanggaran dan kesalahan dalam rencana anggaran, karena penganggaran dana hibah di APBD tidak dibenarkan terus-menerus pada tiap tahun anggaran. Kenyataan berbeda, di mana penganggaran fisik bangunan kampus menjadi beban APBD tiap tahunnya. Dari penelusuran di lapangan ada tanda-tanda akan dianggarkan lagi hibah anggaran fisik kampus di APBD Kabupaten Kuantan Singingi tahun 2017. Hal ini menjadi tantangan tersendiri bagi Kepemimpinan Drs. H. Mursini, M.Si selaku Kepala Daerah bila tetap menganggarkan dana hibah untuk fisik bangunan kampus.

Menurut Permendagri Nomor 32 Tahun 2011 tentang Pedoman Pemberian Hibah dan Bantuan Sosial yang Bersumber Dari Anggaran Pendapatan dan Belanja Daerah pada Pasal 10 Ayat (2) dan (3) menjelaskan bahwa hibah berupa barang atau jasa dicantumkan dalam RKA-SKPD dan RKASKPD sebagaimana dimaksud pada Ayat (2) menjadi dasar penganggaran hibah dalam APBD sesuai peraturan perundang-undangan. Dari aturan ini juga menjadi pertanyaan apa dasar pemerintah Kabupaten Kuantan Singingi dalam penganggaran yang terus berlanjut dalam hibah bangunan kampus perguruan tinggi swasta pada APBD Kabupaten Kuantan Singingi. 


\section{Kesimpulan}

1. Tujuan, persyaratan dan pertanggungjawaban hibah dari pemerintah daerah sekarang dapat berpedoman pada Permendagri Nomor 32 Tahun 2011 yang telah diubah dengan Permendagri Nomor 39 Tahun 2012. Berlakunya Permendagri maka pemberian hibah sejak tahun anggaran 2012 menjadi semakin selektif dan ketat. Kriteria-kriteria sebagai pembatasan pemberian hibah disyaratkan oleh Permendagri dan dapat mengantisipasi terjadinya penyimpangan dalam mekanisme pemberian hibah mulai dari proses pengajuan proposal atau permohonan hibah, penganggaran oleh pemerintah daerah, penetapan dan penyaluran dana hibah, sampai dengan pertanggungjawaban serta monitoring dan evaluasi atas pemberian dana hibah tersebut.

2. Analisis hukum hibah dari Pemerintah Kabupaten Kuantan Singingi untuk pembangunan perguruan tinggi swasta yang menjadi persoalan telah dua kali dianggarkan setiap tahun berturut-turut dalam APBD dengan nomenklatur anggaran hibah yang sama, namun pembangunan fisik tetap tidak terselesaikan. Bila dikaji dari hukum tentu sudah bertentangan dengan Permendagri Nomor 32 Tahun 2011 tentang Pedoman Pemberian Hibah dan Bantuan Sosial yang Bersumber Dari Anggaran Pendapatan dan Belanja Daerah pada Pasal 4 Ayat (4) huruf (b) di mana "tidak wajib, tidak mengikat dan tidak terus menerus setiap tahun anggaran, kecuali ditentukan lain oleh peraturan perundang-undangan".

\section{Saran}

1. Sejak berlakunya Permendagri maka sebaiknya Pemerintah Daerah harus selektif dan ketat dalam memberikan hibah agar tidak penyimpangan dan menimbulkan persoalan hukum.

2. Dalam memberikan hibah dan bantuan sosial yang bersumber dari APBD untuk pembangunan fisik kampus perguruan tinggi swasta di Kabupaten Kuantan Singingi sebaiknya perlu Pemerintah Kabupaten Kuantan Sengingi mempertimbangkan aspek peraturan berkenaan dengan hibah dengan berpedoman pada Permendagri agar tidak terjebak dalam pengunaan anggaran yang bertentangan dengan peraturan perundang-undangan.

\section{Referensi}

Abdulkadir Muhammad. 1990. Hukum Perdata Indonesia. Bandung: Citra Aditya Bakti.

Abdul Aziz Dahlan, et.al. 1996. Ensiklopedi Hukum Islam. Jakarta: PT Ichtiar van Hoeve.

Ahmad Rofiq. 1998. Hukum Islam di Indonesia. Jakarta: PT Raja Grafindo Persada.

Amirudin Fardianzah. Pembatalan Akta Hibah yang Dibuat di Hadapan PPAT Oleh Pemberi Hibah. hukum.studentjournal.ub.ac.id. Malang.

A. W. Munawir. 1997. Kamus Al-Munawir. Surabaya: Pustaka Progresif.

Azni. 2015. Eksistensi Hibah dan Posibilitas Pembatalannya Dalam Perspektif Hukum Islam dan Hukum Positif di Indonesia. Jurnal Pemikiran Islam. Volume 40. Nomor 2. UIN Sultan Syarif Kasim Riau.

Enik Isnaini. Hukum Hibah Wasiat Terhadap Anak Angkat Menurut Hukum Perdata. Jurnal IImu Sosial dan Humaniora. Fakultas Hukum Universitas Islam Lamongan.

Faizah Bafadhal. Analisis Tentang Hibah dan Korelasinya Dengan Kewarisan dan 
Pembatalan Hibah Menurut Peraturan Perundang-Undangan di Indonesia. journal.unja.ac.id. Malang.

Rhonda Remma Prastama, Agus Suryono, Abdul Wachid. Implementasi PengeIolaan Dan Penggunaan Dana Hibah Berdasarkan Peraturan Walikota Malang No. 10 Tahun 2010 tentang Pedoman Penggunaan Dana Hibah Kepada Masyarakat (Studi Pada Kelurahan Ciptomulyo Kecamatan Sukun Kota Malang). Jurnal Adminis- trasi Publik (JAP). Volume 1. Nomor 2. Fakultas IImu Administrasi Jurusan Administrasi Publik. Universitas Brawijaya Malang.

Sayyid Sabiq. 1997. Fikih Sunnah. Jilid 14 (Terjemah). Jakarta: Pena Pundi Aksara.

Yusran Lapananda. 2013. Hibah \& Bantuan Sosial yang Bersumber dari APBD. Jakarta: Sinar Grafika.

Tan Thong Kie. 2011. Studi Notariat, Serbaserbi Praktek Notaris. Jakarta: Ichtiar Baru Van Hoeve. 